PRZEGLĄD NAUK HISTORYCZNYCH 2017, R. XVI, NR 2

http://dx.doi.org/10.18778/1644-857X.16.02.08

DROBNE PRACE I MATERIAEY

SŁaWOMir BralewsKi

UNIWERSYTET ŁÓDZKI*

\title{
Czy według Sokratesa z Konstantynopola i Hermiasza Sozomena kobieta heretyk mogła być piękna?
}

W

Historiach kościelnych autorstwa Sokratesa z Konstantynopola i Hermiasza Sozomena wspominane sa kobiety różnorodnego stanu i statusu społecznego. Jedne wymienione są $z$ imienia, o pozostałych wiadomo jedynie tyle, że były kobietami, matkami, żonami, córkami, wdowami czy dziewicami. Tak czy owak pojawiaja się one w tle narracji historyków na temat dziejów Kościoła ukazanych wespół z wydarzeniami politycznymi. Zarówno Sokrates, jak i Sozomen najwięcej miejsca spośród wszystkich kobiet wspomnianych w swych dziełach poświęcili cesarzowym. Wśród nich znalazła się wyjątkowo piękna kobieta: cesarzowa Justyna, żona Walentyniana I. Dla Sokratesa i Sozomena jako zwolenniczka arianizmu była heretykiem, ale czy heretyk mógł być piękny nawet wtedy, kiedy był kobietą? W jaki sposób Justyna została przedstawiona przez wspomnianych historyków Kościoła? Czy Sokrates i Sozomen, który w dużym stopniu oparł swoja Historie kościelna na dziele Sokratesa ${ }^{1}$, tak samo postrzegali tę cesarzową?

* Wydział Filozoficzno-Historyczny, Instytut Historii, Katedra Historii Bizancjum, e-mail: sbralewski@o2.p1.

${ }^{1}$ Na zależność przekazu Sozomena od Sokratesa zwracano uwagę wielokrotnie. Por G.C. Hansen, Einleintung, [w:] Sozomenus, Kirchengeschichte, eds I. Bidez, G.Ch. Hansen, „Die Griechischen Christlichen Schriftseller”, Neue Folge, Bd. IV, Berlin 1995, s. XLV-XLVII; G.F. Chesnut, The First Christian Histories. Eusebius, Socrates, Sozomen, Theodoret, and Evagrius, Paris 1977, s. 205; G. Sabbah, Introduction, [w:] Sozomène, Histoire Ecclésiastique, vol. I-II, eds B. Grillet, G. Sabbah, „Sources Chrétiennes” no 306, Paris 1983, s. 59; F. Young, From 
Czy Sozomen wprowadził jakieś istotne zmiany w wizerunku owej władczyni stworzonym przez jego poprzednika? Oto pytania, na które postaram się odpowiedzieć w tym artykule, zwłaszcza że mimo rozwijającego się obszaru badań dotyczacych kobiet w późnej starożytności żaden uczony nie zajmował się jeszcze wspomniana kwestią.

Sokrates wprowadza Justynę do swojej narracji w Historii kościelnej $\mathrm{w}$ sensacyjnym watku dotyczacym bigamii $\mathrm{w}$ rodzinie cesarskiej. W jego relacji cesarz Walentynian I za życia swej małżonki Sewery poślubił kolejną żonę Justynę ${ }^{2}$. Historyk podkreślił, że władca, poślubiając druga żonę, nie pozbył się pierwszej, z którą miał syna Gracjana ${ }^{3}$. Mało tego, wydał ustawę i ogłosił ja publicznie, co zaznaczył Sokrates, że każdy poddany, który wyrazi taka

Nicaea to Chakedon, London 1983, s. 32; T.D. Barnes, Athanasius and Constantius. Theology and Politics in the Constantinian Empire, Cambridge 1993, s. 206; T. Urbainczyk, Observations on the differences between the Church Histories of Socrates and Sozomen, „Historia” 1997, vol. XLVI, s. 355-356. Peter van Nuffelen (Un Héritage de Paix et de Piété. Étude sur les histoires ecclésiastiques de Socrate et de Sozomène, Leuven-Paris-Dudley 2004) poświęcił cała monografię porównaniu obydwu Historii kościelnych pod kątem podobieństw i różnic. W przekonaniu Pawła J a n is zew skie go (Żywioły w służbie propagandy, czyli po czyjej stronie stoi Bóg. Studium klęsk i rzadkich fenomenów przyrodniczych u historyków Kościoła w IV i V wieku, [w:] Chrześcijaństwo u schyłku starożytności. Studia źródłoznawcze, red. T. Derda, E. Wipszycka, t. III, Kraków 2000, s. 153) Sozomen „chciał stworzyć konkurencyjne dla Sokratesa dzieło, bliższe kanonom klasycznej literatury i gustom klasycyzujacych środowisk intelektualnych Konstantynopola”. W moim przekonaniu zależność dzieła Sozomena od Sokratesa prawdopodobnie wynikała $\mathrm{z}$ zaangażowania pierwszego $\mathrm{z}$ nich w konflikty wewnątrzkościelne, których kulminacja nastapiła na synodzie efeskim (latrocinium efesinum) w roku 449. Jego Historia kościelna, dedykowana cesarzowi Teodozjuszowi II, mogła być próba przekonania władcy do zmiany prowadzonej przez niego polityki kościelnej, ale żeby odniosła pożądany skutek, musiała być szybko napisana; toteż Sozomen zreinterpretował i rozszerzył napisane wcześniej dzieło Sokratesa; por. S. Bralewski, Obraz papiestwa $w$ historiografii kościelnej wczesnego Bizancjum, Łódź 2006, s. 274-278.

2 Prawdopodobnie miała sycylijskie pochodzenie, gdyż spokrewniona była $z$ wieloma ważnymi rzymskimi rodami. Por J. Rou gé, Justine, la belle Sicilienne, „Latomus” 1974, no 33, s. 676-678. François Chau s s on (Stemmatta Aurea: Constantin, Justine, Théodose. Revendications généalogiques et idéologie impériale au IVe s., Rome 2007, s. 160-188) uważał ja za prawnuczkę Konstancjusza I, czyli krewna Konstantyna Wielkiego. Przez związki z rodem Konstantyna jej pochodzenie wywodzi się z Ilyrii, co ma tłumaczyć jej przekonania ariańskie. Por. D. W o ods, The constantinian origin of Justina (Themistius, Or. 3.43b), „The Classical Quaterly" 2004, No. 54, s. 325-327.

${ }^{3}$ Socrates, Historia ecclesiastica, IV 31, 10; 15, ed. G.C. Han s e n, „Die Griechischen Christlichen Schriftseller”, Neue Folge, Bd. I, Berlin 1995, s. 267-268. 
wolę, będzie mógł poślubić dwie legalne małżonki . Historyk dodat-

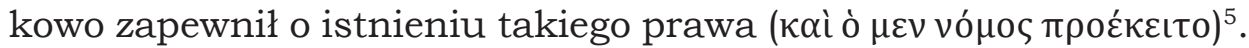
Pikanterii całej sprawie w ujęciu historyka dodawał fakt, że to najpierw Sewera, choć sama była kobieta, zachwyciła się uroda Justyny, dzieląc się swoimi spostrzeżeniami na jej temat $z$ mężem. Sama zaś dobrze poznała wdzięki dziewczyny, która zaopiekowała się „jako będąca bez ojca” ${ }^{\circ}$ d dopuściła do tak bliskiej komitywy, że razem zażywały kapieli, zatem, czego autor nie dopowiedział, nie kryły przed sobą swej nagości ${ }^{7}$. Historyk wskazywał, że Justyna była piękna dziewica ${ }^{8}$. W dalszej swojej relacji podał zaś, że ze związu z Justyną narodził się Walentynian Młodszy oraz trzy córki: Justa, Grata i Galia, z których dwie pierwsze żyły w dziewiczym stanie do śmierci, a Galia została poślubiona przez Teodozjusza I9.

W dalszej swej relacji Sokrates przedstawił Justynę jako wyznawczynię religii ariańskiej ${ }^{10}$, zaznaczając, że za życia swego męża nie miała żadnych możliwości wyrządzania szkód wyznawcom wiary we

4 Socrates, HE IV 31, 16, s. 268.

${ }^{5}$ Socrates, HE IV 31, 17, s. 268. Podobne prawo nigdy nie istniało; por. J. Rou gé, La pseudo-bigamie de Valentinien Ier, „Cahiers d'Histoire” 1958, no 3, s. 5-15; A.D. Manfredini, Valentiniano I e la bigamia, „Studi in onore di Cesare Sanfilippo", Milano 1985, vol. VII, s. 361-386.

${ }^{6}$ Wedle Sokratesa (HE IV 31, 11-12, s. 267) jej ojciec Justyn, zwierzchnik prowincji Picenum, został stracony na polecenie cesarza Konstancjusza II $z$ powodu proroczego snu zapowiadającego, że jego potomek zostanie cesarzem. W rzeczywistości należał do stronników uzurpatora Magnencjusza, skoro wydał za niego córkę (por. Zos imos, Historia nova, IV 19,1; 43,1, ed. F. Paschoud, 2, Paris 1979, s. 279-280; 311) i prawdopodobnie to było przyczyna kary śmierci, która poniósł.

7 Socrates, HE IV 31, 13-14, s. 267-268.

8 Socrates, HE IV 31, 13; 14, s. 267-268. W przekonaniu Jeana Rougé (Justine..., s. 677) „Pour ce qui est de sa beauté, réelle ou non, il nous est impossible de le savoir, elle découle uniquement du récit graveleux de Socrate". Jednak także Zosimos (Historia nova, IV 43,1, s. 311) pisał o jej wyjątkowej urodzie. Prawdopodobnie w tym czasie nie była już dziewica, gdyż związek $z$ Walentynianem był jej drugim małżeństwem, chyba że uznamy jej pierwsze małżeństwo za białe, jak sadził Jean Rougé (Justine..., s. 677). Według Liz J a me s (Empresses and Power in Early Byzantium, London 2001, s. 63-64) Justyna zwróciła na siebie uwagę Walentyniana I dzięki swojemu małżeństwu z uzurpatorem Magnencjuszem.

${ }^{9}$ Socrates, HE IV 31, 17-18, s. 268.

10 Justyna jako zwolenniczka rozwiązań doktrynalnych przyjętych na synodzie w Ariminum należała do homojuzjan. W Mediolanie, którego Kościół przed elekcją Ambrożego zarządzany był w latach 355-373 przez ariańskiego biskupa Auksencjusza (Auxentius), homojuzjanie stanowili poważna siłę. Por. D.W. Williams, Ambrose of Milan and the End of the Arian-Nicene Conflicts, Oxford 1995, s. 78, 112-113; T.D. Barnes, Valentinian, Auxentius and Ambrose, „Historia” 2002, 
współistotność, po jego śmierci zaś, sprawując opiekę nad małoletnim synem, występowała przeciwko Ambrożemu, biskupowi Mediolanu ${ }^{11}$. Wedle historyka zamierzała zesłać go na wygnanie, lecz spotkała się $z$ oporem ludności, która darzac Ambrożego nieprzeciętną sympatią, w czynny sposób przeciwstawiła się wykonawcom jej woli ${ }^{12}$. Dopiero uzurpacja Maksyma i nieoczekiwane zabójstwo cesarza Gracjana, mającego 24 lata, miały uśmierzyć gniew Justyny przeciwko Ambrożemu ${ }^{13}$. Co ciekawe, Rufin z Akwilei, którego Historie kościelna Sokrates znał dobrze, pisał o bezbożności

vol. LI, s. 235-236. Por. też M.S. Williams, Auxentius of Milan: From Orthodoxy to Heresy, „Studia Patristica” 2013, vol. LXVI, s. 263-272.

${ }^{11}$ Socrates, HE V 11, 3-5, s. 285. Podobnie rzecz przedstawił Rufin z Akwilei (Historia ecclesiastica, XI, 15, eds E. Schwartz, T. Mommsen, F. Winkelmann, „Die Griechischen Christlichen Schriftseller”, Neue Folge, Bd. VI, Berlin 1999, s. 1020-1021) i Teodoret z Cyru (Historia ecclesiastica V 13, 1, eds L. Parmentier, G.Ch. Hansen, „Die Griechischen Christlichen Schriftseller”, Neue Folge, Bd. V, Berlin-New York 2009, s. 303). Z relacji samego A m b roże go (Ep. 75a [21a] - Sermo contra Auxentius de basilicis tradendis, ed. M. Zelzer, Vienna 1982, Corpus Scriptorum Ecclesiasticorum Latinorum 82, s. 82-107) wynika, że cesarzowa znajdowała się pod wpływem Merkuryna, ariańskiego biskupa Durostorum, który przybył do Mediolanu ok. 382 r., przyjął imię Auksencjusz (Ep. 75a [21a], 22, s. 96), zmarłego ariańskiego biskupa Mediolanu, poprzednika Ambrożego na biskupim tronie, i zyskał znaczace wpływy na dworze młodego Walentyniana. Por. K. Ilski, Idea jedności politycznej, społecznej i religijnej $w$ świetle pism Ambrożego z Mediolanu, Poznań 2001, s. 310-311. Według Neila M c Ly n n a (Ambrose of Milan. Church and Court in a Christian Capital, Berkeley-Los AngelesLondon 1994, s. 172-173) Walentynianem nie kierowała cesarzowa matka, lecz jakiś wysoki urzędnik dworski.

12 Socrates, HE V 11, 6, s. 285. Por. także Rufinus Aquileiensis, HE XI, 15, s. 1021; Theodoretus Cyrensis, HE V 13, 5-6, s. 304. W rzeczywistości był to konflikt o bazyliki, których dla siebie domagali się arianie wsparci przez Walentyniana II. Por. H.F. Cam pe $\mathrm{n}$ h a u s e n, Ambrosius von Mailand als Kirchenpolitiker, Berlin-Leipzig 1929, s. 192; J.-R. Palanque, Saint Ambroise et l'Empire romain. Contribution à l'histoire des rapports de l'Église et de l'État à la fin du IV siècle, Paris 1933, s. 511-514; F.H. Dudden, The life and times of St Ambrose, Oxford 1935, s. 270-297; A. Le nox-C ony ng ha m, The Topography of the Basilica Conflict of A.D. 385/6 in Milan, „Historia” 1982, vol. XXXI, s. 353-363; K. I1s ki, op. cit., s. 309-318.

13 Socrates, HE V 11, 6-10, s. 285-286. Autor Chronicon Paschale (380, ed. W. Dindorf, Bonnae 1832, s. 562) przypisywał Justynie współudział w zamordowaniu Gracjana, lokujac to wydarzenie w konstantynopolitańskim hipodromie, doszukując się przyczyny na gruncie religijnym. Wskazywał bowiem, że Gracjan był chrześcijaninem, a Justyna arianka. Według Liz J a mes (op. cit., s. 74) podejrzenia te spadły na cesarzowa, gdyż zakładano, że chciała umocnić pozycję swego syna. Na hipodrom jako miejsce zamordowania Gracjana wskazywał wcześniej Jan Malalas (Chronographia, 344, ed. J. Thurn, Berlin-New York 2000, s. 266), który jednak nie czynił żadnych sugestii co do winy Justyny. Na temat śmierci 
(impietas) Justyny ${ }^{14}$, porównując ją do Jezabel, żony króla Achaba i prześladowczyni proroka Eliasza, w Apokalipsie św. Jana, symbolizującej fałszywa prorokinię zwodząca chrześcijan ${ }^{15}$. Jak zatem widać, Sokrates świadomie zrezygnował z przedstawiania Justyny jako bezbożnej.

Mamy zatem w Historii kościelnej Sokratesa złożony obraz cesarzowej Justyny. $Z$ jednej strony historyk przedstawił ja jako niezwykłej urody kobietę, dla której władca nie tylko zdecydował się na bigamię, lecz także postanowił zmienić prawo, dopuszczając możliwość poślubienia dwóch żon, i która dała mu czwórkę potomstwa. Z drugiej jednak strony - jako gorliwa ariankę za życia męża czy to nieobnosząca się ze swymi przekonaniami religijnymi, czy też niemająca nań dostatecznego wpływu w tej materii, aby skłonić go do działań przeciw zwolennikom nicejskiego credo. Historyk wskazywał, że to po śmierci męża Justyna stała się groźna dla wyznawców ortodoksji, o czym mógł się przekonać biskup Ambroży będący wówczas na Zachodzie ich niewątpliwym liderem. Dopiero czynny opór ludności i uzurpacja Maksyma zmusiły ją do zaniechania działań skierowanych przeciwko nicejczykom. W obrazie cesarzowej Justyny wykreowanym przez Sokratesa $z$ Konstantynopola widzimy więc kobietę heretyczkę, co nie przeszkadzało historykowi podkreślać jej nadzwyczajnej urody, z powodu której cesarz wprowadzić miał nowe prawo, umożliwiajace mu jej poślubienie.

Sozomen również pisał na temat Justyny, ale przedstawił ją nieco inaczej. Zrezygnował $z$ opisu jej urody, pominął kwestię bigamii oraz prawa zezwalającego na poślubienie dwóch żon, prawdopodobnie, znając obowiazujące prawo, odrzucił przekaz swego poprzednika jako nieprawdziwy. Skupił się natomiast na jej proariańskich poczynaniach, rozwijajac i poprawiajac przekaz Sokratesa. Wyjaśnił, dlaczego usiłowała doprowadzić do wygnania Ambrożego. Podkreślał więc podobnie do swego poprzednika, że Justyna była

Gracjana por. Chronicon Paschale 284-628 AD, eds M. Whitby, M. Whitby, Liverpool 1989, s. 51, przyp. 159.

${ }^{14}$ Rufinus Aquileiensis, HE XI, 15, s. 1021. Według Rufina Justyna, walcząc z Ambrożym, usiłowała skłócić lud (animare et inflammare ad discordiam populos). Ten zaś przyrównywał ją do Ewy, która zwiodła Adama, do Jezabel, prześladowczyni proroka Eliasza, czy do Herodiady, która kazała zabić Jana Chrzciciela. Por. A. Belleli, Justine en Jézabel. La fabrication textuelle d'une mauvaise impératrice romaine dans la première moitié du Ve siècle, „Revue des Études Tardo-antiques" 2016, no 6, s. 93-107.

15 Ap 2, 20-23. 
zwolenniczką doktryny ariańskiej ${ }^{16}$. Dodał jednak, że usiłowała zapewnić zwycięstwo w Kościele zwolennikom doktryny przyjętej na synodzie w Ariminum ${ }^{17}$, zwalczając naukę soboru w Nicei, przez co wywołała zamęt w życiu kościelnym, i sprawiała wiele kłopotu Ambrożemu, biskupowi Mediolanu. Ponieważ ten stawał w obronie nicejskiej formuły, wywołał gniew cesarzowej, która oskarżyła go przed synem o obrazę ${ }^{18}$. Sozomen wyraźnie sugeruje, że chodziło o oszczercze oskarżenia rozmijające się z prawdą. Walentynian, dając jednak wiarę w oskarżenia matki, skierował przeciwko biskupowi żołnierzy, którzy przypuściwszy szturm do świątyni, przemoca wywlekli z niej Ambrożego, by go wywieźć na wygnanie, jednak nie dopuścili do tego wierni, którzy otoczyli biskupa zwartym pierścieniem i stawili opór żołnierzom, gotowi ponieść śmierć w obronie swojego pasterza ${ }^{19}$.

Na skutek tego wydarzenia Justyna zapałać miała jeszcze większym gniewem przeciwko Ambrożemu i postanowiła popierana przez siebie doktrynę wprowadzić moca prawa. Sozomen dalsza swoją relację oparł ściśle na przekazie Rufina $z$ Akwilei ${ }^{20}$. Wedle niej Benevolus $^{21}$, urzędnik, w przekonaniu Sozomena, odpowiedzialny za stanowienie prawa ${ }^{22}$, wymawiał się od tego jako wyznawca Kościoła powszechnego i nie uległ mimo różnorakich zachęt cesarzowej, kuszony obietnica otrzymania jeszcze zaszczytniejszego urzędu. Benevolus miał demonstracyjnie zdjąć pas $z$ bioder i rzucić go pod stopy władczyni, wskazując, że nie uczyni z piastowanej godności, ani nawet $z$ wyższej, żołdu płaconego za bezbożność $(\alpha \dot{\alpha} \sigma \varepsilon \beta \varepsilon i ́ \alpha \varsigma)^{23}$. Cesarzowa znalazła jednak urzędników, którzy spełnili jej wolę, sformułowali przepis prawny zezwalajacy bez obawy gromadzić się

16 Sozomenus, HE VII 13, 2, s. 316.

17 Pisał o tym wcześniej Rufin z Akwilei (HE XI, 15, s. 1021).

18 Sozomenus, HE VII 13, 3, s. 316. Por. także Rufinus Aquileiensis, HE XI, 15, s. 1021.

19 Sozomenus, HE VII 13, 4, s. 316-317.

20 Rufinus Aquileiensis, HE XI, 16, s. 1021-1022.

${ }^{21}$ PLRE I, s. 161; por. także N. McLynn, op. cit., s. 181; T.D. Barnes, Ambrose and the Basilicas of Milan in 385 and 386: The Primary Documents and their Implications, „Zeitschrift für antikes Christentum” 2002, Bd. IV, s. 292-293.

22 Jak zaznaczył Rufin z Akwilei (HE XI, 16, s. 1021), Benevolus był memoriae sriniis praesidenti. Stał więc na czele scrinium memoriae i jako jego przełożony (magister memoriae) nie miał uprawnień do redagowania prawa. Por. R. Delmaire, Les institutions du Bas-Empire romain de Constantin à Justinien, Paris 1995, s. 65-73.

${ }^{23}$ Sozomenus, HE VII 13, 6, s. 317. 
wszystkim podzielającym poglądy uczestników synodu zebranego w Ariminum, a później w Konstantynopolu; ci natomiast, którzy by im w tym przeszkodzili albo zgłaszali żądania przeciwne zarządzeniu cesarskiemu, mieli być karani śmiercią ${ }^{24}$. Wprowadzeniu w czyn wspomnianych rozporządzeń przeszkodzić miała śmierć Gracjana, gdyż, w przekonaniu Sozomena, Justyna pod wpływem tak wielkiego nieszczęścia poniechała swego gniewu przeciw Ambrożemu, tym bardziej że w kierunku Italii posuwały się wojska uzurpatora Maksyma, który prowadzić miał działania zbrojne pod pretekstem obrony świętej wiary ojców i organizacji Kościoła ${ }^{25}$, a sam Walentynian wraz $z$ matka szukali schronienia w Tessalonice ${ }^{26}$. Ostatecznie, wedle historyka, zwycięstwo Teodozjusza nad uzurpatorem zapewniło Kościołowi w Italii pomyślność, do której przyczynić się miała także naturalna śmierć cesarzowej Justyny ${ }^{27}$.

W relacji Sozomena na temat Justyny mamy więc obraz zawziętej heretyczki ${ }^{28}$, matki młodocianego cesarza, pragnącej narzucić przemoca wyznawana przez siebie doktrynę całemu Kościołowi. Bezwzględnie zwalczającą oponentów, niecofającą się przed oszczerstwem w imię zasady, że cel uświęca środki, o czym przekonał się Ambroży, lider ortodoksów na Zachodzie. Oddającą się bezbożności i odwołująca się do przekupstwa nawet wobec urzędników, byle tylko zrealizować swoje bezbożne zamiary. Wyraźnie zatem Sozomen rozwiną negatywna stronę obrazu cesarzowej stworzonego przez Sokratesa, pominąwszy informacje, które mogłyby ocieplić jej wizerunek, jak te dotyczące jej niezwykłej urody, sieroctwa czy macierzyństwa, wszak obok Walentyniana była jeszcze matka

${ }^{24}$ Sozomenus, HE VII 13, 7, s. 317. W Kodeksie Teodozjusza (XVI, 1, 4, ed. Th. Mommsen, „Sources Chrétiennes” no 497, Paris 2005, s. 118-121) pt. De fide catholica istnieje ustawa Walentyniana Młodszego z dnia 23 I 386 r. zapewniająca wyznawcom formuły synodu w Ariminum swobodę gromadzenia się na nabożeństwa. Ogłoszona została więc trzy lata później, niż zakładał Sozomen, czyli już po śmierci cesarza Gracjana, który był przecież ortodoksem i z którym Justyna musiała się liczyć.

${ }^{25}$ Podobnie na ten temat pisał Rufin $z$ Akwilei (HE XI, 16, s. 1021).

26 Sozomenus, HE VII 13, 8-11, s. 317-318. Wedle Rufina (HE XI, 16, p. 1022) cesarzowa Justynę spotkał los wygnańca, jaki sama przeznaczyła wcześniej dla kapłanów Boga.

27 Sozomenus, HE VII 14, 7, s. 319.

28 Podobny negatywny obraz cesarzowej Justyny znajdziemy u biografa Ambrożego, Paulina $z$ Mediolanu (Vita Ambrosii 11; 15; 20, Patrologiae cursus completus, series latina, ed. J.-P. Mogne, 14), który przedstawił ją nie tylko jako zwolenniczkę arianizmu, lecz także mściwą kobietę targaną złymi emocjami. Por. także L. J a me s, op. cit., s. 153. 
trzech córek, na co Sokrates zwracał uwagę. Prawdopodobnie więc dla Sozomena fakt, że Justyna była zwolenniczką nauki ariańskiej, determinował jej negatywny obraz.

Jak zatem widać, obraz cesarzowej Justyny naszkicowany w Historiach kościelnych Sokratesa i Sozomena bardzo się różni. Pierwszy $z$ nich przedstawił ją w sposób bardziej wszechstronny, drugi - jednostronny. Sokrates zwrócił uwage przede wszystkim na jej piękno, które wzbudzało podziw nie tylko u mężczyzn, lecz także u kobiet. Cesarz, zauroczony nia, jak dowodził Sokrates, zmienił prawo i zalegalizował bigamię, aby się $z$ nią ożenić. Tak więc dziewczyna, która dostała się na dwór cesarski jako sierota, dzięki swym fizycznym walorom stała się cesarzową i urodziła swemu mężowi liczne potomstwo. Informacja o jej heterodoksji została podana przez historyka później, niewątpliwie jako mniej ważna, kiedy ten wspomniał o gniewie cesarzowej na Ambrożego, biskupa Mediolanu. Te negatywne emocje władczyni miały zostać wyciszone w związu z uzurpacja Magnusa Maksymusa i zabójstwem na jego polecenie Gracjana, pasierba Justyny z pierwszego małżeństwa Walentyniana I z Sewerą. Dla Sozomena zaś Justyna to wyłącznie zwolenniczka doktryny ariańskiej, odznaczająca się bezbożnością. Władczyni, która w walce $z$ ortodoksją posługiwała się oszustwem i przemoca, a popierane przez siebie rozwiązania doktrynalne starała sie narzucić moca prawa, przekupujac odpowiedzialnych za jego stanowienie urzędników. W dodatku bezwzględnie zwalczająca swoich przeciwników religijnych, skoro mieli oni być karani śmiercia na mocy wspomnianych rozporządzeń. Przy czym Sozomen świadomie pominą wszystkie wattki $z$ jej życia podnoszone przez poprzednika, które ocieplały jej wizerunek, a dotyczyły jej urody, sieroctwa czy macierzyństwa. Tak więc wyraźnie w przekonaniu Sozomena, w przeciwieństwie do poglądu Sokratesa, piękno nie mogło być atrybutem heretyka.

\section{Bibliografia}

\section{Ź RÓDEA DRUKOWANE}

Ambrosius Mediolanensis, Epistulae, ed. M. Zelzer, Vienna 1982, Corpus Scriptorum Ecclesiasticorum Latinorum 82.

Chronicon Paschale, ed. W. Dindorf, Bonnae 1832.

Chronicon Paschale 284-628 AD, eds M. Whitby, M. Whitby, Liverpool 1989. 
Codex Theodosianus, XVI, ed. Th. Mommsen, „Sources Chrétiennes” no 497, Paris 2005.

Ioannes Malalas, Chronographia, ed. J. Thurn, Berlin-New York 2000.

Paulinus Mediolanensis, Vita Ambrosii, Patrologiae cursus completus, series latina, ed. J.-P.Mogne, 14, 29-50.

Rufinus Aquileiensis, Historia ecclesiastica, eds E. Schwartz, T. Mommsen, F. Winkelmann, „Die Griechischen Christlichen Schriftseller”, Neue Folge, Bd. VI, Berlin 1999.

Socrates, Historia ecclesiastica, ed. G.C. Hansen, „Die Griechischen Christlichen Schriftseller", Neue Folge, Bd. I, Berlin 1995.

Socrate de Constantinople, Histoire ecclésiastique, eds G.C. Hansen, P. Périchon, P. Maraval, „Sources Chrétiennes” no 477, Paris 2004.

Sozomène, Histoire Ecclésiastique, vol. I-II, eds B. Grillet, G. Sabbah, „Sources Chrétiennes" no 306, Paris 1983.

Sozomenus, Historia ecclesiastic, eds I. Bidez, G.Ch. Hansen, „Die Griechischen Christlichen Schriftseller", Neue Folge, Bd. IV, Berlin 1995.

Theodoretus Cyrensis, Historia ecclesiastica, eds L. Parmentier, G.Ch. Hansen, „Die Griechischen Christlichen Schriftseller”, Neue Folge, Bd. V, Berlin-New York 2009.

Zosimos, Historia nova, ed. F. Paschoud, 2, Paris 1979.

\section{Opracowania}

Barnes T.D., Ambrose and the Basilicas of Milan in 385 and 386: The Primary Documents and their Implications, "Zeitschrift für antikes Christentum” 2002, Bd. IV, s. 282-299.

Barnes T.D., Athanasius and Constantius, Cambridge 1993.

Barnes T.D., Valentinian, Auxentius and Ambrose, „Historia” 2002, vol. LI, s. 227-257.

Belleli A., Justine en Jézabel. La fabrication textuelle d'une mauvaise impératrice romaine dans la première moitié du Ve siècle, „Revue des Études Tardo-antiques" 2016, no 6, s. 93-107.

Bralewski S., Obraz papiestwa $w$ historiografii kościelnej wczesnego Bizancjum, Łódź 2006.

Campenhausen H.F., Ambrosius von Mailand als Kirchenpolitiker, Berlin-Leipzig 1929.

Chausson F., Stemmatta Aurea: Constantin, Justine, Théodose. Revendications généalogiques et idéologie impériale au IVe s., Rome 2007.

Chesnut G.F., The First Christian Histories. Eusebius, Socrates, Sozomen, Theodoret, and Evagrius, Paris 1977.

Delmaire R., Les institutions du Bas-Empire romain de Constantin à Justinien, Paris 1995.

Dudden F.H., The life and times of St Ambrose, Oxford 1935.

Ilski K., Idea jedności politycznej, społecznej i religijnej w świetle pism Ambrożego z Mediolanu, Poznań 2001. 
James L., Empresses and Power in Early Byzantium, London 2001.

Janiszewski P., Żywioły w służbie propagandy, czyli po czyjej stronie stoi Bóg. Studium klessk $i$ rzadkich fenomenów przyrodniczych u historyków Kościoła $w$ IV i V wieku, [w:] Chrześcijaństwo u schyłku starożytności. Studia źródłoznawcze, red. T. Derda, E. Wipszycka, t. III, Kraków 2000, s. 5-191.

Lenox-Conyngham A., The Topography of the Basilica Conflict of A.D. 385/6 in Milan, „Historia” 1982, vol. XXXI, s. 353-363.

Manfredini A.D., Valentiniano I e la bigamia, „Studi in onore di Cesare Sanfilippo”, Milano 1985, vol. VII, s. 361-386.

McLynn N., Ambrose of Milan. Church and Court in a Christian Capital, BerkeleyLos Angeles-London 1994.

Nuffelen P. van, Un Héritage de Paix et de Piété. Étude sur les histoires ecclésiastiques de Socrate et de Sozomène, Leuven-Paris-Dudley 2004.

Palanque J.-R., Saint Ambroise et l'Empire romain. Contribution à l'histoire des rapports de l'Église et de l'État à la fin du IV siècle, Paris 1933.

Rougé J., Justine, la belle Sicilienne, „Latomus” 1974, no 33, s. 676-678.

Rougé J., La pseudo-bigamie de Valentinien Ier, „Cahiers d'Histoire” 1958, no 3, s. $5-15$.

Urbainczyk T., Observations on the differences between the Church Histories of Socrates and Sozomen, „Historia” 1997, vol. XLVI, s. 355-373.

Young F., From Nicaea to Chakedon, London 1983.

Williams D.W., Ambrose of Milan and the End of the Arian-Nicene Conflicts, Oxford 1995.

Williams M.S., Auxentius of Milan: From Orthodoxy to Heresy, „Studia Patristica” 2013, vol. LXVI, s. 263-272.

Woods D., The constantinian origin of Justina (Themistius, Or. 3.43b), „The Classical Quaterly" 2004, No. 54, s. 325-327. 